\title{
2 YEARS REVIEW OF SUCCESSFULLY EMPLOYED CLIENTS FROM SUPPORTED EMPLOYMENT PROGRAM IN A COMMUNITY MENTAL HEALTH CENTRE (CMHC) IN MALAYSIA
}

Muhammad Adib Baharom, Anis Hazirah Dzulkarnine, Nur Izzati Che Raimi, Azerin Jopril, Nor Hayati Ali Selayang Community Mental Health Centre (MENTARI Selayang), Department of Psychiatry and Mental Health, Hospital Selayang

\section{OBJECTIVES}

To describe the demography, clinical and employment profile of clients with severe mental illness who were employed via Individual Placement and Support (IPS) Supported Employment program in MENTARI Selayang, a CMHC in Malaysia.

\section{BACKGROUND}

IPS Supported Employment is an evidence-based intervention which focused on recovery. It was started in United States (US) and had been also applied in Asian countries such as Japan and Hong Kong. MENTARI Selayang has established the program since 2015 for clients with severe mental illness.

\section{METHODS}

Records of clients who were successfully employed at any time in 2017 and/or 2018 were reviewed.

\section{DISCUSSIONS}

IPS is the only evidence-based approach to supported employment for people with serious mental illnesses ${ }^{1}$. It is internationally accepted and effective ${ }^{2}$. This study showed favourable outcome in employment profiles in which the clients with severe mental illness were able to sustain employment for more than a year, worked full time and earned minimum wage. There is a growing need for this specialized service and the challenges in implementation and sustainability required collaborative approach between stakeholders, clinical teams, employment services and the service users.

\section{CONCLUSION}

This evidence-based program was successfully applied in Malaysia with sustainable positive outcomes.

\begin{tabular}{|c|c|c|c|c|c|}
\hline \multicolumn{6}{|c|}{ RESULTS } \\
\hline \multicolumn{4}{|c|}{ Demographic and Clinical Profiles $(\mathrm{N}=45)$} & \multicolumn{2}{|l|}{ Employment Profiles ( $\mathrm{N}=45)$} \\
\hline \multicolumn{2}{|l|}{ PROFILES } & \multicolumn{2}{|c|}{ Mean ( \pm SD) } & \multirow{3}{*}{ Duration under the program } & Mean ( \pm SD) \\
\hline \multicolumn{2}{|l|}{ Age } & \multirow{2}{*}{\multicolumn{2}{|c|}{$\begin{array}{l}36.2 \pm 9.9 \text { years old } \\
10.3 \pm 5.8 \text { years }\end{array}$}} & & $2372+132$ months \\
\hline \multirow{2}{*}{\multicolumn{2}{|c|}{ Duration of illness }} & & & & $23.1 .2 \pm 13.2$ months \\
\hline & & $n$ & $\%$ & First successful job placement & $5.2 \pm 4$ months \\
\hline \multicolumn{2}{|c|}{ Gender (Male) } & 33 & 73.3 & & \\
\hline \multicolumn{2}{|c|}{ Ethnicity (Malay) } & 23 & 51.1 & Duration of employment per job & $1.3 \pm 1.2$ years \\
\hline \multicolumn{2}{|c|}{ Marital status (Single) } & 37 & 82.2 & Working hours per week & $46.2 \pm 12.6$ hours \\
\hline \multirow{2}{*}{\multicolumn{2}{|c|}{ Education (Secondary school) }} & 23 & 51.1 & & \\
\hline & Schizophrenia & 23 & 51.1 & Salary per hour & RM8.6 \pm 5.2 \\
\hline \multirow[t]{2}{*}{ Diagnosis } & $\begin{array}{l}\text { Schizoaffective } \\
\text { Disorder }\end{array}$ & 4 & 8.9 & $\begin{array}{l}\text { Sustain employment } 50 \% \text { of the time } \\
\text { during follow up }\end{array}$ & $\mathrm{n}=34(81 \%)$ \\
\hline & Bipolar Disorder & 10 & 22.2 & Past history of employment & $n=43(95.6 \%)$ \\
\hline \multicolumn{2}{|c|}{ No recent admission within 2 years } & 37 & 82.2 & & \\
\hline
\end{tabular}

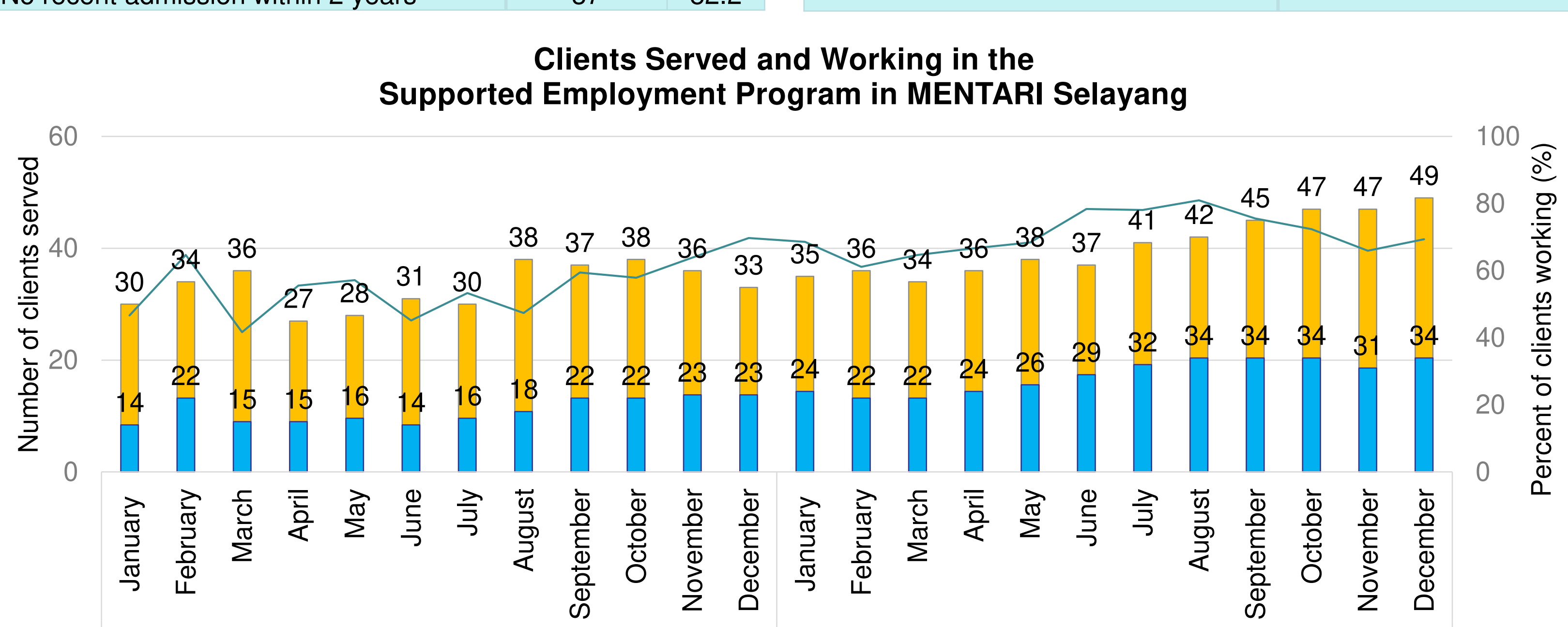

2017

References

$\square$ Served $\square$ Working -Percent working

1 Drake, Robert E., Gary R. Bond, and Deborah R. Becker. Individual Placement and Support: An Evidence-based Approach to Supported Employment. Oxford University Press, 2012.

${ }^{2}$ Hutchinson, Jan, David Gilbert, Rachel Papworth, and Jed Boardman. "Implementing Supported Employment. Lessons from the Making IPS Work Project." International journal of environmental research and public health 15, no. 7 (2018): 1545.

2018 